\title{
Bioactivity of some natural products against the cowpea storage weevil Callosobruchus Maculatus L.
}

\author{
N.S.A. DERKYI ${ }^{1 *}$, S.O. ACQUAAH ${ }^{2}$ and M. OWUSU-AKYAW ${ }^{3}$ \\ ${ }^{I}$ CSIR-Forestry Research Institute of Ghana, KNUST Box 63 Kumasi, Ghana. \\ ${ }^{2}$ Department of Chemistry, KNUST, Kumasi, Ghana. \\ ${ }^{3}$ CSIR-Crops Research Institute, Kumasi, Ghana. \\ *Corresponding author; E-mail: dertch@csir-forig.org.gh ; Tel: +233(0)240161157.
}

\begin{abstract}
This work was carried out to evaluate the insecticidal activity of extracts from 14 plant species of Ghanaian origin against Callosobruchus maculatus adults under laboratory conditions. Phytochemical screenings of the 14 plant species were performed using standard laboratory methods to determine the types of secondary natural products present in the plant species. Aqueous, petroleum ether and ethanolic extracts of the 14 plant species were screened for their bioactivity against Artemia selina in a brine shrimp lethality test. The pesticidal activities of the plant products against Callosobruchus maculatus were investigated in laboratory experiments. Contact toxicity (filter paper impregnation method), grain treatment with plant products for insect population and mortality assays, and also effect of the plant products on grain damage were obtained and compared with Actellic Super EC (synthetic insecticide) during a three-month observation period. Cymbopogan winterianus oil caused the highest mortality, least damage to grains and the highest antireproductive effect. All grain-protective properties of the natural products were concentration and time dependent. Extracts of Cassia alata showed good potential in protecting cowpea and gave better protection than the powder, whilst Griffornia simplicifolia did not significantly protect the grains. Phytochemical investigations of the plants revealed the presence of terpenes, saponins, tannins, glycosides, alkaloids, anthraquinones and flavonoids. The presence of some of these compounds may be responsible for the pesticidal action of the plants.
\end{abstract}

(C) 2010 International Formulae Group. All rights reserved.

Keywords: Phytochemical screening, Extracts, Insecticidal, Brine shrimp lethality test, Cowpea.

\section{INTRODUCTION}

Post-harvest losses are often more significant than crop losses which occur in the field. In Africa as much as $20-50 \%$ of the grain can be lost in maize and pulses because of infestations from weevils, bruchids and other insects (FAO, 1985). Grains constitute the most important staple foodstuff for the ever-growing population in the tropics. As in field crops a wide range of insect pests attack stored products with the commonest among them being beetles and moths (Obeng-Ofori et al., 1997).

Farmers' efforts to increase production of cowpea are hampered by insect pests encountered during storage of the harvested 
produce. Cowpea grains are damaged in storage by the cowpea storage weevil Callosobruchus maculatus (Fabricious Coleoptera: Bruchidae). If the insects are not effectively controlled, grain damage could reach $100 \%$. Grains heavily damaged by storage insect pests fetch lower market price or nothing if declared unfit for human consumption and can cause the farmer heavy financial loss (Owusu-Akyaw, 1994).

Recently, attention has been given to the possible use of bioactive natural products or plant derived compounds as promising alternatives to synthetic insecticides in controlling insect pests of stored products (Schmutterer, 1990; Ohazurike et al., 2003; Umoetok and Gerard, 2003). Owusu-Akyaw (1994) reported that neem seed oil, Jathropa seed oil and groundnut oil were as effective as Actellic $2 \%$ dust and completely controlled $S$. zeamais for six months while neem wood ash and ordinary wood ash controlled only $S$. zeamais up to five and six months respectively. Plants indeed produce economically important secondary metabolites such as alkaloids, oils, terpenoids, tannins, sugars, flavonoids, etc. (Benner, 1993). As pesticides, terpenoids are the most successful (Duke, 1991). A lot of successes have been recorded in the area of protection of stored grains by bioactive natural products (Ogunleye, 2003; 2006; Ogunleye et al., 2003; Omotoso and Ogunleye, 2006).

Botanical insecticides have thus been suggested for preserving cowpea seeds (Owusu-Akyaw, 1994; Osekre and Ayertey, 2002; Boeke et al., 2003; Udo et al., 2004; Ajayi, 2005). Forests therefore serve as nature's reservoir of potent pesticides. The natural products are more rapidly degraded than synthetic compounds and some have increased specificity that favours beneficial insects (Plimmer, 1993). Again, synthetic chemicals are expensive, erratic in supply due to foreign exchange constraints and often not economical to use by resource poor farmers (Niber, 1994; Udo, 2005). Consequently, due to the misuse of such synthetic chemicals and the accompanying undesired effects, the need to revisit traditional pest control options to look for alternatives is very pressing (Owusu, 2001). The objective of the present study therefore was to evaluate the pesticidal activity of extracts and powders of some plants of Ghanaian origin against the cowpea storage weevil C. maculatus.

\section{MATERIALS AND METHODS Collection and extraction}

The leaves of Celtis milbraedii, Mormodica charantia, Plumbago Zeylanica, Cassia alata, Datura innoxia, Hoslondia opposita, Griffornia simpliciforlia, Blighia sapida, Parkia clappertoniana, Khaya senegalensis, Jatropha curcas, Azadirachta indica, Cymbopogan winterianus and the bulb of Allium sativum were collected in the Ashanti and Northern regions of Ghana and were identified by the herbarium keeper at the Forestry Research Institute of Ghana (FORIG). The samples were dried at $40{ }^{\circ} \mathrm{C}$ in an aerated oven for 6 hours. Each was separately powdered to a uniform mesh in an electrical mill and kept in clean, dried polythene bags and bottles until used.

The powdered plant materials $(0.5 \mathrm{~kg}$ each) were extracted successively with petroleum ether (40-60) and ethanol in a soxhlet extractor. Separate $0.5 \mathrm{~kg}$ each of the plant materials were also extracted with water. Each extract was evaporated in a Buchi rotary evaporator R114 and the semi-solid residue obtained, dried to a constant weight in an oven at $60{ }^{\circ} \mathrm{C}$. The essential oil of $C$. winterianus was extracted by employing steam distillation.

\section{Phytochemical screening}

The powdered plant products were screened for the secondary metabolites in them, using the standard methods described by Harborne (1984). All chemicals used were of analytical grade. 


\section{Brine shrimp lethality test (BSLT)}

The brine shrimp lethality test was carried out using the standard procedure as described by Meyer et al. (1982) and McLaughlin (1991). Stock solutions of concentration $10,000 \mathrm{ppm}$ were prepared by dissolving the extracts in methanol. From each of these solutions, serial dilutions were made to obtain the concentrations 1000, 500, 100, 50 and $10 \mathrm{ppm}$. Each concentration was replicated three times and the vial with only sea water served as a control.

Brine shrimp eggs (A. salina Leach) were hatched in a hatching tank filled with artificial sea water. Ten brine shrimps were counted into each vial using a micrometer pipette. These were left for twenty-four hours, after which the number of deaths out of the 30 shrimps per dose was recorded, with the aid of a hand lens (Meyer et al., 1982; McLaughlin, 1991). The $\mathrm{LC}_{50}$ value at $95 \%$ confidence interval was determined from the count using the statistical method of Probit analysis (Finney, 1971; Sauders and Fleming, 1971).

\section{Contact toxicity on filter paper}

The filter paper impregnation method (FPIM) was performed to rapidly screen the pesticidal activity of the plants collected, by estimating the $\mathrm{LC}_{50}$ values within 24 hours to select the plant extracts that showed promise for pesticidal activity. Stock solutions of concentration 10,000 ppm were prepared by dissolving the plant extracts in their respective solvents. From each of these solutions, serial dilutions were made to obtain the concentrations 2000, 1000, 500, 100 and 10 ppm.

For each solution, a $9 \mathrm{~cm}$ filter paper was laid in a Petri dish of a similar diameter and $1 \mathrm{ml}$ of the solution poured from a pipette to cover the whole of the filter paper and left in a fume chamber overnight for all the solvents to evaporate. Ten Sitophilus zeamais adults were counted onto the filter paper and covered with a mesh to allow aeration and prevent the insects from moving out or foreign materials from entering. Mortalities were recorded after $30 \mathrm{mins}, 1 \mathrm{hr}, 3 \mathrm{hrs}, 6 \mathrm{hrs}, 12$ hrs and $24 \mathrm{hrs}$. A control experiment was also set up using the pure solvents. The experiment was replicated three times.

\section{Pesticidal activity of plant products on $C$. maculatus}

The cowpea weevil, C. maculatus (from a laboratory breeding stock) was used for this experiment at $27 \pm 1^{\circ} \mathrm{C}$ and $65 \pm 5 \%$ R.H. There were three replicates and each consisted of 5 males and 5 females (0-1 day old) on $500 \mathrm{~g}$ of clean and un-infested cowpea seeds maintained in $750 \mathrm{ml}$ kilner jars. The seeds were separately treated with 0.5 and $0.05 \mathrm{~g}$ petroleum ether and ethanolic extracts of C. alata (rates of 0.1 and $0.01 \%$ respectively) and $10 \mathrm{~g}$ and $5 \mathrm{~g}$ of selected powdered plant products to give rates of $2 \%$ and $1 \%$ respectively. Actellic Super EC (a synthetic insecticide, was used as standard to compare with the natural products) was thoroughly mixed with the cowpea at the rate of $0.02 \%$. Untreated cowpea served as a control. Number of eggs laid was recorded after 2 weeks. Mortality and population of insects as well as damaged seeds were recorded monthly for 3 months. The weevil perforation index (WPI) was calculated using methods described by Fatope et al. (1995). The contents of each kilner jar were emptied into a large bowl and the records taken.

\section{Data analysis}

Data obtained were subjected to oneway analysis of variance (ANOVA) and differences between means were determined using the least significant difference (LSD) statistic at $\mathrm{P}<0.05$.

\section{RESULTS}

Qualitative phytochemical investigation revealed the presence of saponins, glycosides, terpenoids, tannins, alkaloids, flavonoids and anthraquinones, as indicated in Table 1. The results showed that $A$. indica demonstrated the 
presence of all phytoconstituents tested whilst glycosides and saponins were found to be present in all the plants tested.

From the 42 plant extracts (14 plants $x$ 3 extracts each) evaluated in the BSLT, only 17 were bioactive. $C$. winterianus (petroleum ether extract), A. indica (ethanol extract), $A$. sativum (petroleum ether extract), D. innoxia (ethanol extract) and C. alata (ethanol extract) were the most active with $\mathrm{LC}_{50}$ values of 7.8 , $12.3,29.7,31.7$ and $43.5 \mathrm{ppm}$ respectively. The least active of the bioactive extracts were $J$. curcas (petroleum ether extract), $K$. senegalensis (ethanol extract) and H. opposita (ethanol extract) with $\mathrm{LC}_{50}$ values of 197.9, 279.9 and 284.3 ppm respectively.

The results of the effect of the various extracts applied on filter paper indicated that Cymbopogan winterianus (petroleum ether extract), $A$. indica (ethanol extract), $A$. sativum (petroleum ether extract) and C. alata (ethanol extract) with low $\mathrm{LC}_{50}$ values of 7.8 , 12.3, 29.7 and 43.5 ppm respectively, showed considerable contact toxicity to $C$. maculatus. No significant effect was observed for the other plant products against $C$. maculatus. Powdered A. indica, A. sativum, J. curcas, $C$. alata (together with the petroleum and ethanolic extracts) and $C$. winterianus oil were thus selected for the storage tests.

The production of eggs, hatching and adult emergence in $C$. maculatus were significantly reduced when raised on cowpeas treated with the natural products (Fig. 1). In all treatments except treatment with $C$. winterianus oil, insect population (dead and alive) increased with an increase in length of storage period (Fig. 2a - 2c). There were significant differences between treatments in insect mortality (Table 2). The toxicity of the plant extracts applied on grains against $C$. maculatus showed a significant difference $(\mathrm{P}$ $<0.05$ ) in mortality over the control. Mortality ranged from $51 \%$ to $100 \%$ (month 1), $46 \%$ to $100 \%$ (month 2) and $35.5 \%$ to $100 \%$ (month 3 ) for all the treatments as against $16.3 \%$ to $21.3 \%$ for the control.
In all treatments, percentage damaged seeds increased with an increase in duration of the study period (Fig. $2 \mathrm{a}-2 \mathrm{c}$ ). The least grain damage was caused by $C$. winterianus.

Positive protectant ability was offered by petroleum ether and methanol extracts of Cassia alata compared to the powder (Table 3).

The effect of the plant products on the insects showed that severe damage (weevil perforation index) to the grains was caused by Griffornia simplicifolia and Jatropha curcas powders from the second month and Cassia alata powder from the third month (Table 3).

\section{DISCUSSION}

The identified chemical compounds which are naturally occurring in most plant materials are known to be pesticidal, bactericidal and fungicidal in nature thus conferring the pesticidal activity to plants ( $\mathrm{Su}$, 1977; Bowers et al., 1976). The presence of some of these compounds has been demonstrated previously by other researchers (Bell, 1980; Elliger, 1976). However some of the results obtained are not in agreement with some previous findings. For instance saponins and glycosides were found to be present in the bulb of $A$. sativum which is contrary to the findings of Aqil et al. (2006). This might be due to genetic and/or environmental factors.

The brine shrimp lethality test (BSLT) and the filter paper impregnation method (FPIM) were employed to rapidly access the pesticidal potential of the various plant parts. According to Meyer et al. (1982) and Parra et al. (2001), LC $_{50}$ values lower than 1000 ppm are considered bioactive in toxicity evaluation of plant extracts by BSLT. It is possible that extracts that showed least activity in the 24 hours bioassay will be effective at longer exposure time. Rose and Sparks (1984) observed that acephate required much longer exposure period to produce mortality compared to other organo-phosphates. $G$. simplicifolia was also, therefore, selected for 
the storage tests although it had an $\mathrm{LC}_{50}$ value greater than $1000 \mathrm{ppm}$.

The bioassay used in the study is a quick way of determining the bioactivity of natural products (McLaughlin, 1991). Using the brine shrimp lethality test for bioactivity, guided screening and fractionation, McLaughlin (1991) has been able to rapidly detect and isolate a variety of novel chemically bioactive compounds. The results indicate that there may be sufficient scientific evidence for the folkloric pesticidal activity ascribed to some of the indigenous plants as observed by Owusu-Akyaw (1994).

A significant contact action on filter paper treated with the plant extracts against $C$. maculatus is noteworthy and strongly indicates the presence of insecticidal properties in the plant (Udo and Epidi, 2009). C. maculatus adults are good fliers and the little contact on treated surface produced significant insect mortality (Udo and Epidi, 2009). Contact toxicity on treated grains was observed for $C$. maculatus probably because of their soft bodies making it possible for easy penetration of toxicants (Udo and Epidi, 2009).

The plant extracts were effective in reducing the population of $\mathrm{F} 1$ generation of $C$. maculatus in treated grains. $C$. maculatus was observed to produce lower number of F1 progeny probably because eggs of $C$. maculatus are laid on the seed coat thus exposing them to direct contact with toxic secondary plant metabolites (Udo and Epidi, 2009). It would also appear that progeny inhibition of $C$. maculatus in treated grains could arise from the inability of young adult insects to chew through the seed coats of treated grains due to the presence of phenolic compounds (Wongo, 1998). The significant reduction in $\mathrm{F} 1$ progeny confirms the possible presence of ovicidal and larvicidal constituents in the plant extracts (Tanzubil, 1991). Ovicidal action of some plants was also observed by Makanjuola (1989). Similarly, Lale and Abdulrahman (1999) and
Lale and Mustapha (2000) reported a significant reduction in egg laying and adult emergence in C. maculatus treated with neem seed oil. Ivbijaro (1983a) also reported a significant reduction in egg laying of $C$. maculatus on cowpeas mixed with neem seeds. Neem oil treatment also reduces oviposition, inhibits adult emergence and development of C. maculatus, C. chinensis and $C$. analis (Babu et al., 1989).

The severe damage to the grains caused by Griffornia simplicifolia and Jatropha curcas powders from the second month and Cassia alata powder from the third month is an indication of negative protectant ability. The highest mortality recorded by $C$. winterianus in the present study may be due to the active toxic compound present in the volatile oil that could block the microphyle region of the egg chorion, effecting embryo mortality due to depletion of oxygen for respiration Jayakumar et al. (2003). On the other hand, the plant extracts might have interfered with the normal embryonic development by suppressing hormonal and biochemical processes. Similar physiological interferences were observed by Ofuya et al. (1992) and Jayakumar et al. (2003).

The increase in damaged seeds due to increase in duration of the study period may be attributed to an increase in the total number of cowpea weevils with time and degradation of the effectiveness of the protectants with time. The positive protectant ability offered by petroleum ether and methanol extracts of Cassia alata is an indication that there are some insecticidal properties in the test plant which are not available or potent in the powder form, but could however be extracted and made available by petroleum ether and methanol. As observed by Makanjuola (1989) and Ogunleye (2000), insecticidal plant powders may be more potent through extraction using appropriate solvents.

The significant reduction in damage caused by the insect species to stored grains coupled with high insect mortality could be 
attributed to the presence of toxic secondary metabolites. It has been reported that some secondary metabolites may act both as insecticides and antifeedants as observed for rotenone against T. castaneum (Nawrot et al., 1989).

Bioactive natural products with insecticidal properties are being used as grain protectants against weevils in storage (Guillaume et al., 2005). In the present study, the low grain damage due to $C$. winterianus treatment might be due to decrease in adult emergence that resulted in less damage. Members of the genus Cymbopogan are rich in geraniol content to which insecticidal property is attributable. A. indica is globally acclaimed as insecticidal (Ivbijaro, 1983a; 1983b, 1990; Tanzubil 1991; Das, 1995).

\section{Conclusion}

All grain-protective properties of the natural products were concentration- and time-dependent, and their insecticidal effectiveness in the three-month storage period was similar to that of the filter paper impregnation method. Extracts of Cassia alata showed good potential in protecting cowpea and gave better protection than the powder, whilst Griffornia simplicifolia did not significantly protect the grains. The results obtained in the study suggest good potential for the use of Cymbopogan winterianus, Azadirachta indica, Allium sativum and Cassia alata in storage pest management systems, as botanicals are broad spectrum in action and safer to the environment with fewer hazards to man and other mammals. Phytohemical investigations of the plants revealed the presence of terpenes, saponins, tannins, glycosides, alkaloids, anthraquinones and flavonoids. The presence of some of these compounds may be responsible for the pesticidal action of the plants.

\section{REFERENCES}

Ajayi FA. 2005. Insecticidal efficacy of three non-volatile edible oils on
Callosobruchus maculatus (F.) infesting stored cowpea seeds in Lafia, Nigeria. Production Agriculture and Technology, 1: 105-114.

Aqil F, Ahmad I, Mehmood Z. 2006. Antioxidant and free radical scavenging properties of twelve traditionally used Indian medicinal plants. Turk J. Biol., 30: 177-183.

Babu TR, Reddy VS, Hussaini SH. 1989. Effect of edible and nonedible oils on the development of the pulse weevil, Callosobruchus chinensis (L.) and on viability and yield of mugbean (Vigna radiata (L.) Wilczek). Tropical Sci., 29: 215-220.

Bell EA, Quershi, MY, Pryce RJ, Jansen DH, Lemke P, Clardy J. 1980. 2,4Methanoproline (2-carboxy-2,4-methanopyrolidine) and 2,4-methanoglutamic acid (1-amino-1,3-dicarboxycyclobutane) in seeds of Ateleia herbet smithii Pittier (Leguminosae). J. Am. Chem. Soc., 102: 1409-1412.

Boeke SJ, Antonia AC, Rauls WM, Gilsang PJ, Dansai KK, Jrop JA. 2003. Side effects of cowpea treatment with botanical insecticides on two parasitoiuds of Callosobruchus maculatus. Entomologia Experimentalis at Applicata, 108: 43-51.

Bowers WS, Ohta T, Cleere JS, Marsella PA. 1976. Discovery of insect anti-juvenile hormones in plants. Science, 193: 542547.

Das GP. 1995. Plants used in controlling the potato tuber moth Phathorimaea operculella (Zeller). Crop Protection, 14: 631-636.

Duke SD. 1991. Plant terpenoids as pesticides: toxicology of plant and fungal compounds. In Handbook of Natural Toxins. pp 269-289.

FAO. 1985. Handling and storage of food grains. Food and Agriculture Organization of the United Nations, Rome. 
Fatope MO, Mann A, Takeda Y. 1995. Cowpea weevil bioassay: a simple prescreen for plants with grain protectant effects. Internationl Journal of Pest Management, 41: 84-86.

Finney DJ. 1971. Probit Analysis (3rd edn). Cambridge University Press.

Guillaume KK, Koumaglo HK, Glitho IA. 2005. Inhibition of Callosobruchus maculatus (F.) (Coleoptera: Bruchidae) development with essential oil extracted from Cymbopogan schoenanthus L. Spreng. (Poaceae), and the wasp Dinarmus basalis (Rondani) (Hymenoptera: Pteromalidae) Journal of Stored Products Research, 41(4): 363371.

Harborne JB. 1984. Phytochemical Methods: A Guide to Modern Techniques of Plant Analysis. Chapman and Hall.

Ivbijaro MF. 1983a. Preservation of cowpea, Vigna unguiculata (L.) Walp. with the neem seed Azadirachta indica A. Juss. Prot. Ecol., 5: 177-182.

Ivbijaro MF. 1983b. Toxicity of neem seed, Azadirachta indica A. Juss to Sitophilus oryzae (L.) in stored maize. Prot. Ecol., 5: 353-357.

Jayakumar M, Elumalai K, Jeyasankar A, Raja N, Ignachimuthu S. 2003. Efficacy of crude extracts of Hyptis suaveolens and Melochia chororifolia on pulse weevil Callosobruchus maculatus (F.) (Coleoptera: Bruchidae). Proceedings in Biological Control of Insect Pests. pp 219- 223.

Lale NS, Abdulrahman HT. 1999. Evaluation of neem (Azadirachta indica A. Juss) seed oil obtained by different methods and neem powder for the management of Callosobruchus maculatus (F.) (Coleoptera: Bruchidae) in stored cowpea. J. stored Prod. Res., 35: 135143.

Lale NS, Mustapha A. 2000. Potential of combining neem (Azadirachta indica A. Juss) seed oil with varietal resistance for the management of the cowpea bruchid, Callosobruchus maculatus (F.). J. stored Prod. Res., 36: 215-222.

Makanjuola WA. 1989. Evaluation of extracts of neem (Azadirachta indica A. Juss) for the control of some stored product pests. J. stored Prod. Res., 25(4): 231-237.

McLaughlin JL. 1991. Methods in Plant Biochemistry. In Assays for Bioactivity, Hostettman K (ed). Academic Press: London; 1-33.

Meyer BN, Ferrigni NR, Putnam JE, Jacobsen LB, Nichols DE, McLauglin JL. 1982. Brine shrimp: a convenient general bioassay for active plant constituents. Planta Med., 45: 31-34.

Ofuya TI, Okoye BC, Olola AS. 1992. Efficacy of a crude extract from seeds of Monodora myristics (Gaem.) Dunal as surface protectant against Callosobruchus maculatus (F.) attacking legume seeds in storage. J. Stored Prod. Res., 31(3): 221 228.

Nawrot J, Harmatha J, Kosotova I, Ognyanov I. 1989. Antifeedant activity of Rotenone and some derivatives towards selected insect storage pests. Biochemical Systematic Ecology, 7(1): 55-57.

Obeng-Ofori D, Reichmuth $\mathrm{CH}$, Bekele J, Hassanali A. 1997. Biological activity of 1,8 cineole, a major component of essential oil of Ocimum kenyense (Ayobangira) against stored product weevils. J. Appl. Entomol., 121: 237-243.

Ohazurike NC, Onuh MO, Emeribe EO. 2003. The use of seed extracts of the physic nut (Jatropha curcas L.) in the control of maize weevil (Sitophilus zeamais) in stored maize grains (Zea mays L.). Global J. Agric. Sci., 2(2): 86-88.

Omotoso OT, Ogunleye RF. 2006. Insecticidal and antiovipositional properties of some aromatic medicinal plants of Callosobruchus maculatus. J. Ultra Sci. Phys. Sci., 18(2):181-186.

Osekre EA, Ayertey JN. 2002. Control of the cowpea weevil, Callosobruchus 
maculatus (F) on stored cowpea using Vegetable oils. Ghana J. Agric. Sci., 35: 76-80.

Owusu-Akyaw M. 1994. Evaluation of Plant Products for the control of Cowpea and maize Storage Insects. Ghana Grains Development Project C.R.I., Kumasi, Ghana.

Owusu EO. 2001. Effect of some Ghanaian plant components on control of two stored-product insect pests of cereals. Journal of Stored Products Research, 37: 85-91.

Parra AL, Yhebra RS, Sardinas IG, Buela LI. 2001. Comparative study of the assay of Artemia salina $\mathrm{L}$. and the estimate of the medium lethal dose (LD50 value) in mice, to determine oral acute toxicity of plant extracts. Phytomedicine, 8(5): 395400.

Plimmer JR. 1993. Regulatory problems associated with natural products and biopesticides. Pestic Sci., 39: 103-108.

Rose RL, Sparks TC. 1984. Acephate toxicity, metabolism and anticholinesterase activity in Heliothis virescens and Anthonomus grandis grandis. Pestic Biochem Physiol., 22: 69-77.

Sauders L, Fleming R. 1971. Mathematics Statistics for use in the Biological and Pharmaceutical Sciences (2nd edn). The Pharmaceutical Press: London; 225-286.

Schmutterer H. 1990. Properties and potential of natural pesticides from neem tree, Azadirachta indica. Ann. Rev. Entomol., 35: 271-297.

Su HCF. 1977. Insecticidal properties of black pepper to rice weevils and cowpea weevils. J. Econ. Ent., 70: 18-21.

Sujatha A, Punnaiah KC. 1985. Effect of coating stored seeds of green gram with vegetable oils on the development of pulse weevil. Indian J. Agric. Sci., 55: 475-477.

Tanzubil PB. 1991. Control of some insect pests of cowpea Vigna unguiculata with neem (Azadirachta indica A Juss) in Northern Ghana. Tropical Pest Management, 37: 216-217.

Umoetok SA, Gerard MB. 2003. Comparative efficacy of Acorus calamus powder and two synthetic insecticides for control of three major insect pests of stored cereal grains. Global J. Agric. Sci., 2(2): 94-97.

Udo IO. 2005. Evaluation of the potential of some local spices as stored grain protectants against maize weevil Sitophilus zeamais Mots (Coleoptera: Curculionidae). J. Appl. Sci. Environ. Manage., 9(1): 165-168.

Udo IO, Owusu EO, Obeng-Ofori D. 2004. Efficacy of candlewood Zanthoxylum xanthoxyloides (Lam) for the control of Sitophilus zeamais (Mots.) (Coleoptera: Curculionidae) and Callosobruchus maculatus F. (Coleoptera: Bruchidae). Global Journal of Agricultural Sciences, 3(1): 19-23.

Udo IO, Epidi TT. 2009. Biological effect of ethanolic extract fractions of Ricinodendron heudelotii (Baill) Pierre ex Pax against Sitophilus zeamais Motschulsky and Callosobruchus maculatus Fabricius on stored grains. African Journal of Agricultural Research, 4(10): 1080-1085.

Wongo LE. 1998. Biological activity of sorghum tannin extracts on the stored grain pests Sitophillus oryzae (L.), Sitotroga cerealella (Olivier) and Tribolium castaneum (Herbst). Insect Science and its Application, 18: 17-23. 